\title{
Review
}

\section{Importance of RNA-Protein Interactions in Bacterial Rihonuclease P Structure and Catalysis}

\author{
J. Kristin Smith, ${ }^{1}$ John Hsieh, ${ }^{1}$ Carol A. Fierke ${ }^{1,2}$ \\ ${ }^{1}$ Department of Chemistry, University of Michigan, 930 N. University Avenue, Ann Arbor, MI 48109 \\ ${ }^{2}$ Department of Biological Chemistry, University of Michigan, 930 N. University Avenue, Ann Arbor, MI 48109
}

Received 13 July 2007; revised 4 September 2007; accepted 4 September 2007

Published online 14 September 2007 in Wiley InterScience (www.interscience.wiley.com). DOI 10.1002/bip.20846

\section{ABSTRACT:}

Ribonuclease $P$ (RNase $P$ ) is a ribonucleoprotein (RNP) complex that catalyzes the metal-dependent maturation of the $5^{\prime}$ end of precursor $t R N A s$ (pre-tRNAs) in all organisms. RNase $P$ is comprised of a catalytic RNA (P RNA), and at least one essential protein (P protein). Although P RNA is the catalytic subunit of the enzyme and is active in the absence of $P$ protein under high salt concentrations in vitro, the protein is still required for enzyme activity in vivo. Therefore, the function of the $P$ protein and how it interacts with both $P$ RNA and pretRNA have been the focus of much ongoing research. $R N A$-protein interactions in $R$ Nase P serve a number of critical roles in the RNP including stabilizing the structure, and enhancing the affinity for substrates and metal ions. This review examines the role of RNA-protein interactions in bacterial RNase P from both structural and mechanistic perspectives. (C) 2007 Wiley Periodicals, Inc. Biopolymers 87: 329-338, 2007.

Keywords: ribozyme; ribonucleoprotein; RNase P; Review

Correspondence to: Carol A. Fierke; e-mail: fierke@umich.edu Contract grant sponsor: NIH Training

Contract grant number: T32 GM08353

Contract grant sponsor: National Institutes of Health

Contract grant number: GM55387

\section{WILEY \\ InterScience}

@ 2007 Wiley Periodicals, Inc.
This article was originally published online as an accepted preprint. The "Published Online" date corresponds to the preprint version. You can request a copy of the preprint by emailing the Biopolymers editorial office at biopolymers@wiley. com

\section{INTRODUCTION}

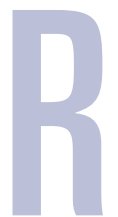

ibonucleoprotein complexes (RNPs) are involved in a plethora of essential processes in nature, including protein translation, ${ }^{1,2}$ mRNA splicing, ${ }^{3,4}$ telomere maintenance, ${ }^{5}$ rRNA maturation, ${ }^{6}$ and tRNA maturation. ${ }^{7,8}$ A subset of these essential RNA-protein complexes is ribozymes, molecules wherein an RNA catalyzes the chemistry of the reaction. The ribosome and ribonuclease $\mathrm{P}$ (RNase P) are among the most extensively studied and universally conserved ribozymes, and they are also the only naturally occurring catalytic RNAs identified so far that are capable of multiple turnover reactions.

RNase $\mathrm{P}$ is a ubiquitous ribonucleoprotein complex that catalyzes the maturation of the $5^{\prime}$ end of precursor tRNAs (pre-tRNAs) by cleaving a specific phosphodiester bond to yield a mature tRNA with a $5^{\prime}$ phosphate (Figure 1). Bacterial RNase $\mathrm{P}$ recognizes and cleaves a variety of RNAs, not just pre-tRNAs, that possess a motif in which a short $5^{\prime}$ single stranded RNA flanks a short duplex RNA stem. ${ }^{9}$ Examples of in vivo substrates for RNase $\mathrm{P}$ include pre-4.5S RNA, pretmRNA, a few mRNAs, and riboswitches. ${ }^{10-14}$ In addition to tRNA maturation, RNase P might also be involved in degrading mRNA and regulating gene expression in vivo. ${ }^{10,15}$ Therefore, there is active research aimed at using RNase $\mathrm{P}$ for gene-therapy or antimicrobial targets. ${ }^{16,17}$

RNase $\mathrm{P}$ is comprised of a catalytic RNA and associated protein(s), with both modules being required for the in vivo function of this essential enzyme. ${ }^{18}$ Although RNase $\mathrm{P}$ has been studied for over 20 years, the vital roles of the protein 

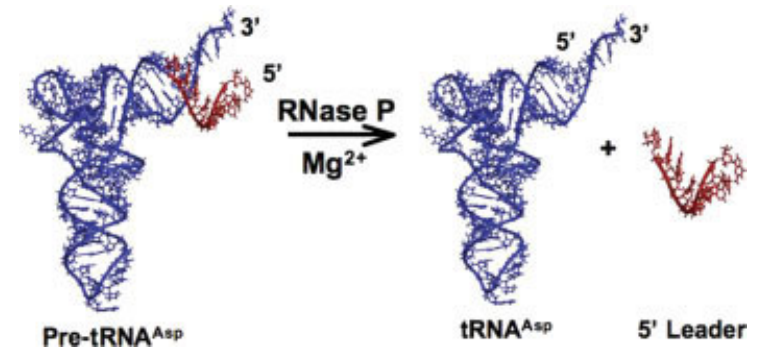

FIGURE 1 RNase P catalyzes the metal dependent cleavage of the $5^{\prime}$ end of precursor tRNAs to form a mature tRNA (blue) and $5^{\prime}$ leader (red).

have been thoroughly investigated only recently. Recent experiments on bacterial RNase $\mathrm{P}$ have revealed roles for the protein and protein-RNA interactions as varied as stabilization of the holoenzyme complex, alteration of the conformation of P RNA, enhancement of pre-tRNA substrate recognition and affinity, and alteration of metal affinity and location. ${ }^{19-23}$ Therefore, a synopsis of the published data is warranted to shed some light on the intriguing role of the $P$ protein in RNA-protein interactions within bacterial RNase $\mathrm{P}$. These interactions will be the focus of this review.

The large RNA (P RNA) components of the RNase P holoenzyme complexes from Escherichia coli and Bacillus subtilis were two of the first ribozymes discovered. ${ }^{24}$ Subsequently, the catalytic activities of the P RNA subunit alone from Archea and Eukaryotes have been demonstrated in vitro, furthering the idea that RNase $\mathrm{P}$ is an ancient and conserved RNA enzyme. ${ }^{25,26} \mathrm{P}$ RNA is the component of the holoenzyme that directly catalyzes substrate cleavage in all three domains of life; however, the P protein modestly enhances the single turnover cleavage rate constant in bacteria at saturating metals. ${ }^{20,27}$ The protein component has a larger effect on the observed RNase P-catalyzed cleavage rate constant at subsaturating substrate and metals. Like many ribozymes, RNase P catalysis is both metal and $\mathrm{pH}$ dependent. ${ }^{19,28,29}$ However, unlike catalysis by small ribozymes that produce a $2^{\prime}, 3^{\prime}$-cyclic phosphate and a $5^{\prime}$ hydroxyl group, ${ }^{30-32}$ RNase P catalyzes the cleavage of a specific phosphodiester bond that produces $5^{\prime}$ phosphate and $3^{\prime}$ hydroxyl end groups. ${ }^{33,34}$ These observations suggest that different chemical mechanisms are used by small ribozymes compared with RNase P.

The number of proteins associated with the catalytic $\mathrm{P}$ RNA varies greatly between Bacteria, Archea, and Eukaryotes. In vitro reconstitution of RNase P holoenzyme from Archea requires at least four proteins while nine proteins are associated with the yeast nuclear enzyme. ${ }^{26,33,35-37}$ In contrast, bacterial RNase $\mathrm{P}$ has the simplest holoenzyme configuration, consisting of one protein and a single P RNA, thereby providing a tractable system in which to investigate P RNA-pro- tein interactions in this conserved RNP. ${ }^{38}$ Bacterial RNase P protein ( $\mathrm{P}$ protein) is essential in vivo, indicating that RNAprotein interactions play a central role in the function of this enzyme. ${ }^{18}$ The functional requirement of RNase Ps from all three domains for a structurally similar $\mathrm{P}$ protein highlights the importance of understanding the role of RNA-protein interactions, and how they contribute to the overall RNase P catalyzed reaction.

\section{BACTERIAL RNASE P}

Prior to discussing RNA-protein interactions in RNase P, a brief introduction into the structure and mechanism of the bacterial enzyme will be given. The composition of bacterial RNase $\mathrm{P}$, a single $\mathrm{P}$ protein associated with the P RNA, makes it the most straightforward, and therefore comprehensively studied RNase P to date. Bacterial RNase P enzymes are classified into two groups based on their P RNA secondary structures, typified by the organisms E. coli and B. subtilis, referred to as A-type (Ancestral type) and B-type (Bacillus type) RNase Ps. ${ }^{39}$ Interestingly, the P RNAs from these organisms are similar enough that the $B$. subtilis $\mathrm{P}$ protein can promote E. coli P RNA activity and vice versa in vitro. ${ }^{22,23,40}$ Recently, type A and B RNase P RNAs were also shown to be interchangeable with each other in vivo, hinting that the $\mathrm{P}$ protein recognizes a region of structure that is conserved between the two classes of bacterial RNase Ps. ${ }^{41}$ Additionally, B. subtilis $\mathrm{P}$ protein can modestly enhance the activity of some archael $\mathrm{P}$ RNAs as well, suggesting both that the binding site for $\mathrm{P}$ protein is conserved and that one or more of the functions of the $\mathrm{P}$ protein is also conserved throughout all three domains of life. ${ }^{42}$

The structure of P RNA is central to its ability to catalyze pre-tRNA cleavage. RNase P RNAs consist of two domains, the substrate binding domain (S-domain) and the catalytic domain (C-domain). ${ }^{39,43}$ These domains can fold independently and the catalytic domain alone retains RNase P activity. ${ }^{4-46}$ The S-domain has been shown to bind the T stemloop regions of pre-tRNA and increase substrate affinity and specificity. ${ }^{45,47,48}$ High resolution X-ray crystal structures of the S-domain from both type A and B P RNAs have been solved. ${ }^{49,50}$ Although the S-domains of the two types of $\mathrm{P}$ RNA differ in both secondary structure and overall fold, the cores of the substrate domains are remarkably similar and likely preserved for recognition of pre-tRNA. ${ }^{50}$ The crystal structures of full-length type A (from T. maritima) and type B (from B. stearothermophilus) P RNAs have been solved. ${ }^{7,51,52}$ Although only about two-thirds of the P RNAs are resolved in the structures, the data reveal similar features in the catalytic cores of both P RNAs, including the coaxial stacks in $\mathrm{P} 1 / \mathrm{P} 4 / \mathrm{P} 5, \mathrm{P} 2 / \mathrm{P} 3$, and $\mathrm{P} 8 / \mathrm{P} 9$ (Figure 2). 

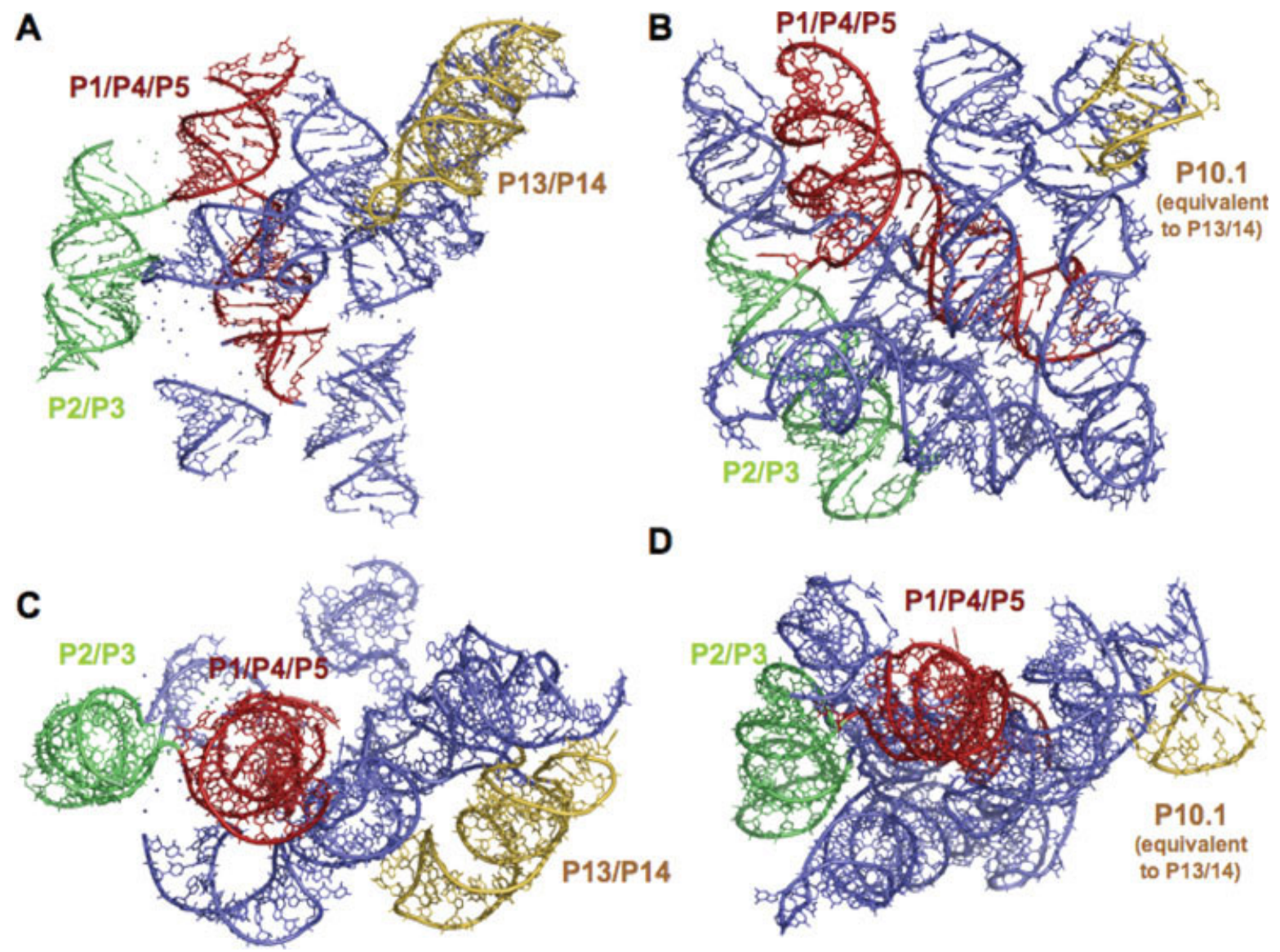

FIGURE 2 Crystal structures of bacterial RNase P RNAs. (B) and (C) show two different views of the B. stearothermophilus P RNA structure. ${ }^{51}$ (A) and (D) illustrate two views of the T. maritima P RNA structure. ${ }^{52}$

A conformational change in the P RNA has been proposed to occur upon both $\mathrm{P}$ protein and substrate binding (Figure 3). ${ }^{22,53}$ The substrate-induced conformational change in the holoenzyme is suggested in the kinetic mechanism of the enzyme (Scheme 1). ${ }^{20,56,57}$ Given that the X-ray crystal structures of RNase P RNA or holoenzyme complexed with either pre-tRNA or tRNA are not yet available, the conformation observed in the published P RNA crystal structures might not reflect the catalytically active form. As a result, multiple models of the holoenzyme complex have been proposed ${ }^{58-60}$ and will be discussed in detail later.

Although RNase P RNA can cleave substrate in the absence of $\mathrm{P}$ protein in vitro under high salt concentrations, the $\mathrm{P}$ protein is necessary for RNase $\mathrm{P}$ cleavage in vivo, presumably enhancing the catalytic activity at low metal ion concentrations. ${ }^{18,21,61,62} \mathrm{P}$ protein enhances $k_{\mathrm{cat}} / K_{\mathrm{M}}$ values catalyzed by the $B$. subtilis holoenzyme for cleavage of the pre-tRNA ${ }^{\text {Asp }}$ by 2000-fold over that of P RNA alone under steady-state conditions and moderate concentrations of magnesium. ${ }^{19}$ However, under single turnover conditions with saturating concentrations of B. subtilis RNase $\mathrm{P}$ and metal ions, the cleavage rate constant for pre-tRNA ${ }^{\text {Asp }}$ is enhanced by $<10$-fold, suggesting that the $\mathrm{P}$ protein does not directly stabilize the cleavage transition state relative to the ground state. ${ }^{27,47,63,64}$

While the P protein modestly effects the global folding of P RNA, it also provides a number of other contributions in addition to assisting folding. ${ }^{65,66}$ For instance, B. subtilis $\mathrm{P}$ protein contacts the $5^{\prime}$ leader sequence of pre-tRNA in the RNase P•pre-tRNA complex to enhance the affinity of the holoenzyme for pre-tRNA ${ }^{\text {Asp }}$ substrate by 10,000 fold. ${ }^{27}$ Although the presence of the protein does not always have the exact same effect for all pre-tRNA substrates, as demonstrated for E. coli RNase P, it does consistently increase both the affinity of the enzyme for substrate and enhance cleavage rate constants. ${ }^{20}$ The fact that the impact of the protein can be different for distinct substrates indicates that the role of the protein may be more complicated than originally anticipated. ${ }^{20}$ Accordingly, the $\mathrm{P}$ protein is proposed to play a 


\section{Catalytic Domain}

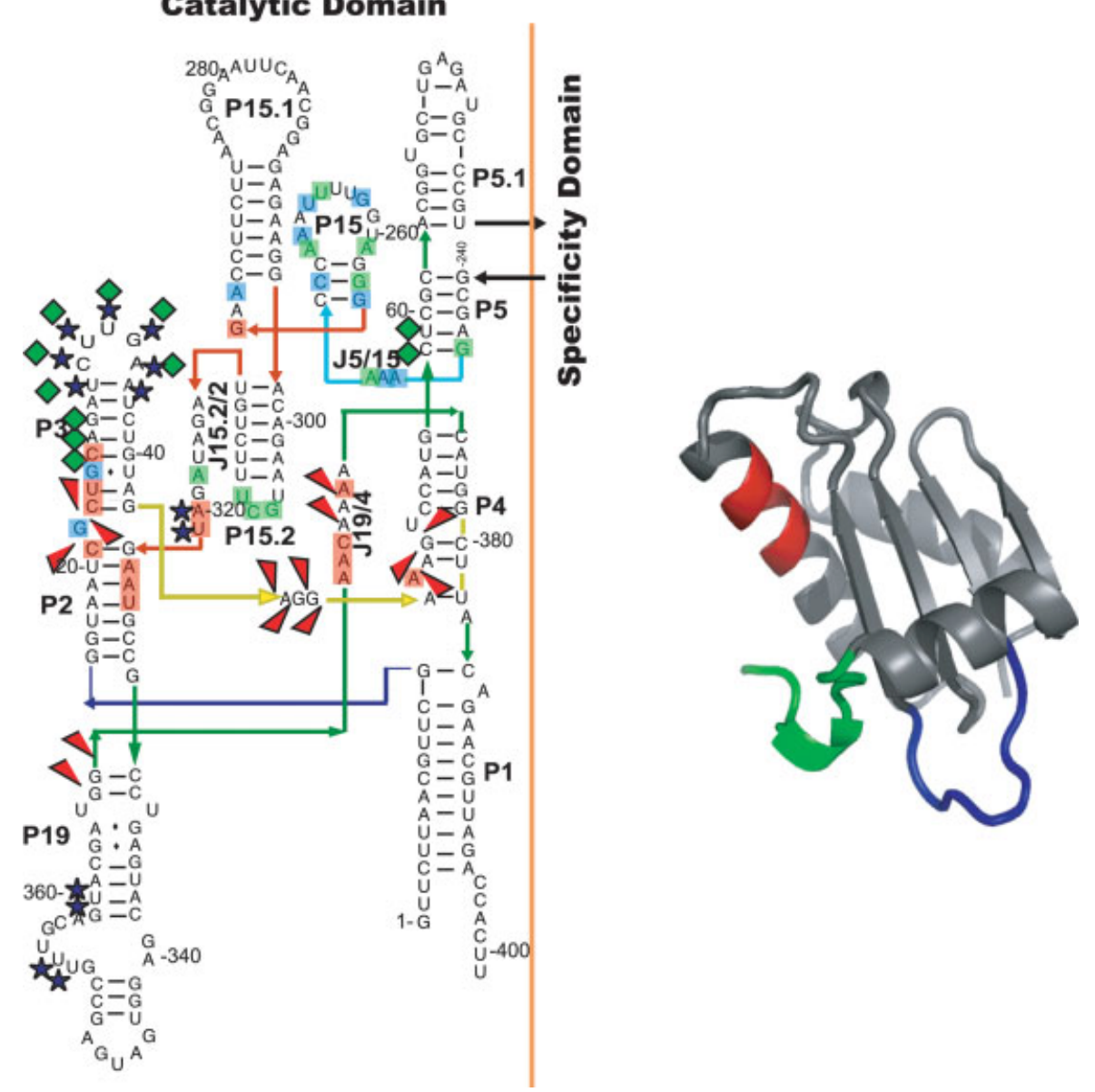

FIGURE 3 Interaction between B. subtilis RNase P RNA and P protein. (Left) Secondary structure of the catalytic domain of B. subtilis P RNA, based on topology from the X-ray structure of the B. stearothermophilus PRNA indicating sites that are cleaved by copper-o-phenanthroline-labeled $\mathrm{P}$ proteins in the following regions: green diamonds, $\mathrm{N}$ terminus; red arrows, RNR motif; and stars, the metal binding loop (MBL).$^{58}$ Additionally, highlighted nucleotides indicate sites where P protein binding reduces (red), enhances (blue) or has a variable effect (green) on cleavage during in-gel Fe(II)-EDTA cleavage assays. ${ }^{23}$ (Right) Structure of B. subtilis $\mathrm{P}$ protein. ${ }^{70}$ Labels indicate the location of the N-terminus (green), the RNR motif (red), metal binding loop (blue), and central cleft (gray).

direct role in substrate recruitment. ${ }^{67-69}$ Additionally, the concentration of magnesium ions required to activate catalysis is also significantly reduced in the RNase P holoenzyme compared with P RNA alone. ${ }^{21,62}$ Given the known and proposed functions of the bacterial $\mathrm{P}$ protein, including assisting in P RNA folding, and recruitment of substrates and metal ions, understanding RNA-protein interactions is key to gaining a comprehensive understanding of RNase $\mathrm{P}$.

The structure of the B. subtilis RNase $\mathrm{P}$ protein was first solved by X-ray crystallography to $2.8 \AA$ resolution. ${ }^{70}$ This protein adopts an $\alpha-\beta$ sandwich fold and is structurally homologous to other RNA binding proteins, including the C-terminal domain of ribosomal protein S5 and domain VI of elongation factor $\mathrm{G}^{70}{ }^{7}$ The crystal structure of the B. subtilis $\mathrm{P}$ protein reveals three distinct regions that might be able to interact with RNA: an unusual left-handed $\beta \alpha \beta$ connec-

$$
\mathrm{E}+\mathrm{S} \underset{k_{-1}}{\stackrel{k_{1}}{\longrightarrow}} \mathrm{ESS} \underset{k_{-2}}{\stackrel{k_{2}}{\longrightarrow}} \mathrm{ES} \stackrel{k_{\text {chem }}}{\longrightarrow} \mathrm{EPL} \underset{k_{-3}}{\stackrel{k_{3}}{\longrightarrow}} \mathrm{E}+\mathrm{P}+\mathrm{L}
$$

SCHEME 1 In this mechanism, RNase P holoenzyme (E) binds pre-tRNA (S) to form an enzyme-substrate complex (ES). This complex then undergoes a conformational change to form $\mathrm{ES}^{*}$. The enzyme then catalyzes the $5^{\prime}$ cleavage of pre-tRNA to form the RNase $\mathrm{P}-$ mature tRNA- $5^{\prime}$ leader complex (EPL). The $5^{\prime}$ leader and mature tRNA then dissociate from the RNase $\mathrm{P}$ holoenzyme. $^{53,63,95}$ 
tion that contains the highly conserved RNR motif, a central cleft formed by four anti-parallel $\beta$-strands and flanked by an $\alpha$-helix, and the "metal binding loop" which contains a cluster of polar residues that bind two zinc ions in the crystal structure (Figure 3)..$^{55,70-71}$ Despite the low sequence similarity among the RNase $\mathrm{P}$ proteins, the three dimensional structure of the B. subtilis $\mathrm{P}$ protein is similar to that of the $S$. aureus and T. maritima $\mathrm{P}$ proteins. ${ }^{72,73}$ Additionally, the structure of a protein subunit from archeal RNase P, a homolog of the eukaryotic RNase P protein Pop5p, ${ }^{54}$ is also similar to that of the bacterial $\mathrm{P}$ protein, suggesting a similar functional role across all three kingdoms of life. ${ }^{74}$

The RNR motif is the most conserved feature of bacterial $\mathrm{P}$ proteins, and is proposed to stabilize binding interactions between the $\mathrm{P}$ protein and $\mathrm{P}$ RNA in the holoenzyme. ${ }^{70,71}$ The metal binding loop in the B. subtilis protein is not a well-conserved feature of $\mathrm{P}$ proteins, but these residues may increase the affinity of the holoenzyme for metal ions. ${ }^{70}$ Cross-linking and affinity cleavage studies indicate that the central cleft of the $\mathrm{P}$ protein is vital to the recognition of pretRNA substrates by the RNase P complex. ${ }^{58}$ Specifically, the central cleft is proposed to interact with the $5^{\prime}$ leader of the pre-tRNA substrates. ${ }^{68,69}$ RNase $\mathrm{P}$ protein forms multiple interactions with both of the RNAs in the RNase P system, the pre-tRNA substrate and the P RNA enzyme. These interactions as well as their implications on RNase P activity and catalysis will be analyzed further in the discussion.

\section{STRUCTURAL PERSPECTIVES ON RNA-PROTEIN INTERACTIONS IN THE RNASE P HOLOENZYME}

Although crystal structures of each of the three components of the bacterial RNase P system (P RNA, P protein, and pretRNA) have been solved independently of one another, no high-resolution structure of the RNase P holoenzyme, or the holoenzyme pre-tRNA complex have been solved thus far. Therefore, our best understanding of the holoenzyme and substrate-bound complexes are structural models of $E$. coli (A type), ${ }^{47,59}$ B. stearothermophilus (B type), ${ }^{22}$ and B. subtilis (B type) RNase P. ${ }^{58,59}$ Although these holoenzyme models differ in detail from the recently published P RNA structures, the overall topology of P RNA in each of these models and the X-ray structures is similar. ${ }^{58}$ Therefore, we will focus on the recent B. subtilis and B. stearothermophilus RNase P holoenzyme pre-tRNA and holoenzyme tRNA complex models, respectively (Figure 4).

For the development of the B. subtilis holoenzyme pretRNA model presented in Niranjanakumari et al. structural calculations were performed starting from the X-ray crystal structure of the $\mathrm{P}$ protein, and a model of the P RNA ${ }^{\circ}$ pretRNA complex (Figures 4B and 4D)..$^{58,70,75}$ Structural constraints were obtained from hydroxyl radical cleavage catalyzed by copper-o-phenanthroline probes positioned at a number of sites in the $\mathrm{P}$ protein via site-specific modification of single cysteines. ${ }^{58}$ This probe requires direct contact with the RNA for cleavage, therefore providing more constrained distances between the cleavage site and $\mathrm{P}$ protein than other cleavage reagents. ${ }^{58}$ In this model, key regions of the $\mathrm{P}$ protein are in close proximity $(<15 \AA)$ to functionally important regions of P RNA and pre-tRNA (Figures $4 \mathrm{~B}$ and $4 \mathrm{D}$ ). For example, the central cleft of the $\mathrm{P}$ protein is proximal to the $5^{\prime}$ leader sequence of pre-tRNA, and the metal binding loop and N-terminus of the P protein are near the P3 stem-loop of P RNA. Additionally, the model places the conserved RNR motif close to the P RNA helix P4 (Figure 4D). Further evidence for the $\mathrm{P}$ protein contacting the catalytic portion of the P RNA is provided by the demonstration that the affinities of the $\mathrm{P}$ protein for the catalytic domain of P RNA and full-length P RNA are nearly identical. ${ }^{40}$ The proximity of the RNR motif in the P protein to the P RNA helix P4 may be noteworthy because this is the most highly conserved region of the P RNA, possessing 11 of the 21 unchanging nucleotides in P RNA. ${ }^{76-79}$ Moreover, P4 is necessary for positioning divalent metal ions required for catalysis, and is the putative active site of the holoenzyme. ${ }^{76-79}$

A model of the B. stearothermophilus RNase P holoenzyme tRNA complex has been developed from in-gel probing of iodine-induced cleavage of thiophosphate-labeled B. stearothermophilus and E. coli P RNAs. ${ }^{22}$ This model places the $\mathrm{P}$ protein binding site in the same general location of P RNA as the B. subtilis model. However, the two models differ in the orientation of the P protein relative to P RNA and in the specific contacts between the P protein and P RNA, with the $B$. stearothermophilus model predicting more extensive interactions between tRNA and the RNR motif of $\mathrm{P}$ protein than the B. subtilis model. Figures $4 \mathrm{C}$ and $4 \mathrm{D}$ highlight the position of the conserved RNR motif in the two B type holoenzyme models. $^{22,58}$ The structural resolution of both models is only about $10 \AA$, and therefore specific contacts proposed by these models will need further evaluation. In fact, given that the models are based on two entirely different sets of biochemical data and are still similar to each other within their $10 \AA$ resolution lends validity to both models.

A number of biochemical and biophysical studies have been undertaken to probe the effect of interactions between the P RNA and the P protein on the structural fold and stability of the holoenzyme. These studies support the idea that $\mathrm{P}$ protein binds a conserved area of the P RNA, stabilizing the local P RNA structure, as well as stabilizing the P RNA 
A

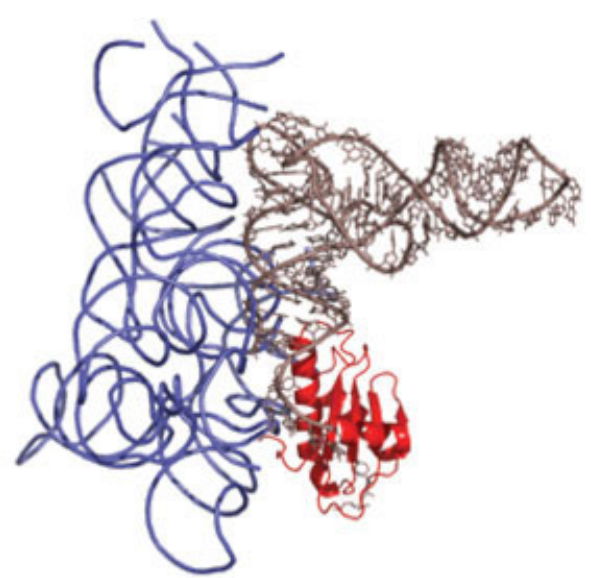

C

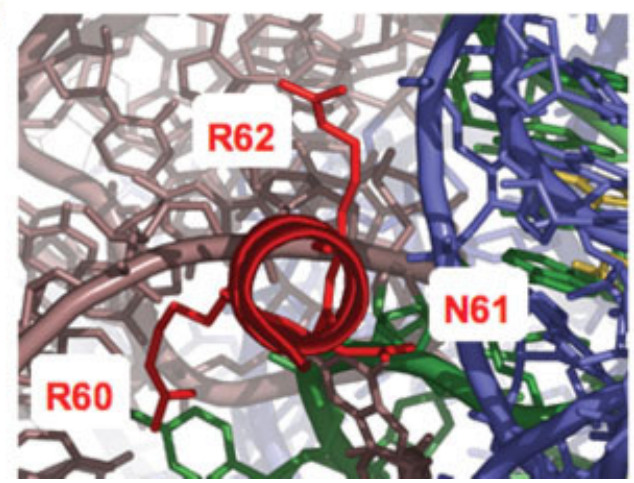

B

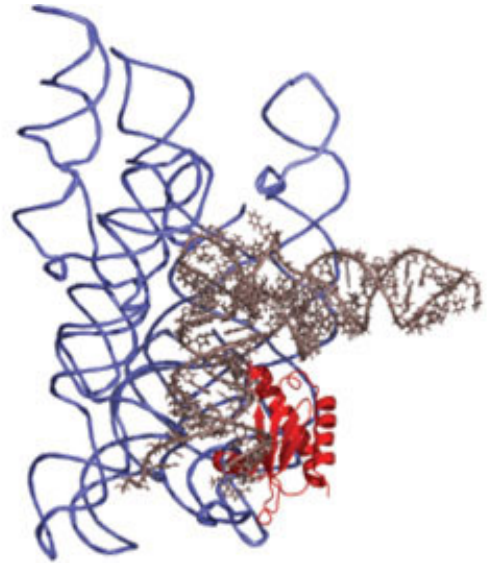

D

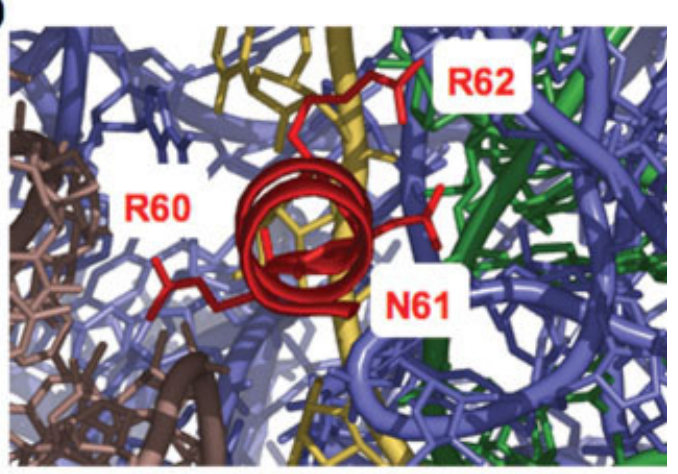

FIGURE 4 Structural models of RNase P holoenzyme with substrate bound from (A) B. stearothermophilus (B) B. subtilis. ${ }^{22,58} \mathrm{P}$ RNA is shown in blue, $\mathrm{P}$ protein shown in red, and yeast tRNAPhe (A) and B. Subtilis pre-tRNAAsp (B) in brown. The P protein is positioned to interact with both P RNA and the $5^{\prime}$ end of substrates in both models. A closer look at the position of the most highly conserved region of the P protein, the RNR motif, is shown for the B. stearothermophilus (C) and the B. subtilis (D) RNase P models. Both models place this region of the protein at the interface of the tRNA, P protein, and P RNA. Helix P4 is colored green and J19/4 is highlighted in yellow in the P RNAs of (C) and (D).

contacts with the pre-tRNA substrates. ${ }^{22,23,80}$ The proposed structural roles of the $\mathrm{P}$ protein in E. coli (A type), and $B$. subtilis (B type) RNase $\mathrm{P}$ holoenzymes have recently been investigated further with melting studies that provide evidence that there is a link between protein binding and the conformation of the P RNA structure. ${ }^{23}$

Moreover, binding to P RNA also stabilizes the bacterial P protein structure. Folding studies have demonstrated that the B. subtilis $\mathrm{P}$ protein is predominately in an unfolded state in solution or is "natively unfolded" in the absence of anions; the folded state of $\mathrm{P}$ protein observed in the crystal structure is stabilized by bound anions. ${ }^{81,82}$ Consistent with this, Harris and coworkers employed thermal melting studies, intrinsic fluorescence, and CD spectral experiments to confirm that both the $\mathrm{P}$ RNA and P protein from E. coli undergo conformational changes upon holoenzyme formation, and that P RNA stabilizes the folding of the E. coli P protein. ${ }^{80}$ These data therefore indicate that there is a link between the folding of $\mathrm{P}$ protein and P RNA and the holoenzyme formation. By determining the salt-dependence of P RNA-P protein affinity, Day-Storms et al. established that there are three to four ions that dissociate upon formation of B. subtilis RNase P holoenzyme. ${ }^{40}$

The RNase P holoenzyme from both E. coli and B. subtilis can dimerize or aggregate under a variety of conditions as demonstrated by small angle X-ray scattering (SAXS), native gel, and light scattering analyses. ${ }^{22,23,83,84}$ The dimerization is inhibited by the presence of the substrate, and proposed to be primarily due to contacts between the P RNA and P protein subunits. ${ }^{22,23,83,84}$ The in vivo relevance of the dimer is still unclear and is one aspect of RNase P structure that needs further investigation.

Overall, RNA-protein interactions in the RNase P holoenzyme contribute significantly to the function of this molecule. P RNA and P protein stabilize each other's structures, 
and the proximity of $\mathrm{P}$ protein to pre-tRNA and the P RNA active site in the holoenzyme models suggests that RNA-protein interactions may be key for forming the proper active site conformation in low salt and metal conditions. Additionally, RNA-protein interactions may contribute to other less well-characterized structural aspects of the holoenzyme, including dimerization. ${ }^{84}$

\section{PRE-tRNA SUBSTRATE RECOGNITION}

The contact between pre-tRNA and P protein during RNase $\mathrm{P}$ substrate recognition is the best-studied aspect of RNAprotein interactions in this RNP. RNase P cleaves the $5^{\prime}$ leader of all pre-tRNAs, and therefore must be able to recognize a wide variety of substrates. ${ }^{9,11,85}$ In addition, the protein component significantly enhances the ability of the E. coli RNase $\mathrm{P}$ to catalyze pre-4.5S rRNA cleavage in vitro, likely by enhancing the affinity of the holoenzyme for this substrate. ${ }^{11,24,64}$ Biochemical data suggest that there are extensive interactions between the P RNA and the pre-tRNA substrate near the cleavage site, D-loop, T-stem loop and acceptor stem, as well as an extensively characterized base pairing interaction with the $3^{\prime}$ CCA. ${ }^{45,46,81,86-91}$ The $3^{\prime}$ CCA contact has been shown to be necessary in vivo for efficient pre-tRNA processing. ${ }^{41}$ The P RNA C-domain is proposed to recognize the pre-tRNA acceptor stem, cleavage site, and the conserved CCA sequence on the $3^{\prime}$ end of the pre-tRNA. ${ }^{56,87,88,91-93}$ In contrast, Pan and coworkers demonstrated that the S-domain of P RNA interacts with the T-stem loop of pre-tRNA. ${ }^{45,94,95}$ Notably, there may be differences in how A type and B type RNase P enzymes discriminate between their substrates; the B. subtilis $\mathrm{P}$ protein causes a much larger enhancement of the affinity of the holoenzyme for pre-tRNA compared with mature tRNA than the E. coli $\mathrm{P}$ protein. ${ }^{23}$ This is possibly inherent to the P RNAs, because the loss of substrate/product discrimination is still seen in chimera RNase P holoenzymes formed with $E$. coli $\mathrm{P}$ protein and $B$. subtilis $\mathrm{P}$ RNA and visa versa. ${ }^{23}$ However, even given the differences, the $\mathrm{P}$ protein enhances substrate discrimination in both classes of RNase P. Furthermore, the importance of the $\mathrm{P}$ protein ${ }^{\circ}$ pre-tRNA leader interaction may vary with the structure of the pretRNA and the concentrations of metals and salts. ${ }^{20}$ Thus far, no sequence specific substrate contacts between the substrate and the $\mathrm{P}$ protein have been reported.

RNase $P$ recognizes a variety of atypical substrates, including pre-tRNAs that lack some of the canonical recognition elements. To better understand these interactions, Fierke and coworkers analyzed the effect of the P protein on the kinetic scheme for cleavage of a pre-tRNA that contains all of the canonical recognition elements (pre-tRNA ${ }^{\text {Asp }}$ from B. subtilis).
They demonstrated that P RNA binds mature tRNA with an affinity slightly higher than pre-tRNA, while the $B$. subtilis holoenzyme has a significantly higher affinity for pre-tRNA than for tRNA. ${ }^{27,67}$ The holoenzyme preference for binding pre-tRNA over mature tRNA by B. subtilis RNase P holoenzyme suggests the formation of a direct contact between the pre-tRNA $5^{\prime}$ leader and $\mathrm{P}$ protein in the holoenzyme. This interaction is confirmed by photo-crosslinking and affinity cleavage studies demonstrating that the $5^{\prime}$ leader of pre-tRNA is in close proximity to the central cleft, but not to the RNR motif or metal binding loop of the P protein. ${ }^{58,68}$ Furthermore, time-resolved fluorescence resonance energy transfer studies further show that the fourth to seventh nucleotides of the $5^{\prime}$ leader contact the $\mathrm{P}$ protein in $B$. subtilis RNase P. ${ }^{69}$ Harris and coworkers recently demonstrated that E. coli RNase P holoenzyme has similar affinity for all of the E. coli pre-tRNAs, regardless of sequence variation, while the affinity of P RNA for this same group of pre-tRNA substrates had significant variation. ${ }^{20}$ Therefore, interactions between the $\mathrm{P}$ protein and pre-tRNAs contribute to the uniformity of the binding affinity for RNase P for pre-tRNAs. Specifically, uniform binding is the result of variations in the energetic contributions between the $5^{\prime}$ leader and $\mathrm{P}$ protein, which serves to compensate for weaker interactions between P RNA and pre-tRNA. Similarly, the observed uniformity in cleavage rates can also be attributed to $\mathrm{P}$ protein contributions for some pre-tRNAs that lack conserved sequence elements, such as the $3^{\prime} \mathrm{CCA}^{20}$ This is consistent with a mechanism in which the effects of the $\mathrm{P}$ protein on the affinity of RNase $\mathrm{P}$ for pre-tRNA are related to a conformational change that accompanies substrate binding. ${ }^{20,56,87,95}$ This is very similar to what has also been seen for the recognition of amino-acylated tRNAs by EF-Tu; here variations in the tRNA sequences lead to alterations in the affinity for EF-Tu compensating for the different thermodynamic contributions of the esterified amino acid to yield uniform affinity for the amino-acylated tRNAs. ${ }^{96,97}$ These data clearly demonstrate that the $\mathrm{P}$ protein plays an important role in substrate recognition in RNase $\mathrm{P}$, allowing the enzyme to bind and cleave a wide array of substrates with comparable efficiency.

\section{RNA-PROTEIN INTERACTIONS AND METAL DEPENDENT CATALYSIS}

Many RNAs require magnesium ions for their catalytic action including RNase $\mathrm{P}^{98,99}$ RNase $\mathrm{P}$ needs divalent metal ions for a number of functions including folding, substrate binding and catalysis. ${ }^{21,29,100,101}$ The binding sites of magnesium ions essential for catalysis have not yet been clearly delineated, although several sites, including positions in helix 
P4, have been implicated in metal binding. ${ }^{102,103}$ RNase P holoenzyme reaches optimal catalytic activity at lower magnesium ion concentrations than the P RNA ribozyme alone. ${ }^{21,104,105}$ Since current holoenzyme models place the $\mathrm{P}$ protein in close proximity to the P RNA P4 helix (see above), the $\mathrm{P}$ protein is ideally positioned to influence these critical metal binding sites, either by interacting with P RNA to indirectly alter metal binding, or by directly interacting with essential magnesium ions.

However, the precise mechanism through which the $\mathrm{P}$ protein enhances metal affinity of the holoenzyme is not yet entirely understood. Thus far, it has been impossible to distinguish metal ions that stabilize P RNA structure important for catalysis from metal ions that directly stabilize the reaction transition state. To further complicate analysis of the effects of metal ions in the RNase $\mathrm{P}$ holoenzyme, a large number of magnesium ions interact non-specifically with the backbones of P RNA and pre-tRNA, through Coulombic interactions to neutralize the net negative charge of the polyanion and thereby stabilize a folded structure. ${ }^{106}$ Nonspecifically bound magnesium ions may also stabilize the formation of negative charge in a cleavage reaction. ${ }^{107}$

Several lines of observation suggest that a magnesium ion specifically binds to a site in helix $\mathrm{P} 4$, the same area of the $\mathrm{P}$ RNA that cross-links to the $P$ protein, and where the putative catalytic site of the enzyme is located. First, deletion of the P4 helix dramatically reduces RNase P activity. ${ }^{77,108}$ Second, sulfur substitution at the nonbridging oxygens at the phosphodiester bonds on nucleotides A49 and A50 in B. subtilis (A67 and A68 in E. coli) in helix P4 decreases the cleavage rate constant enormously without affecting the affinity of pre-tRNA, and some of these reductions in activity can be recovered by adding manganese ions. ${ }^{77,79,102}$ Harris and coworkers provide evidence that the formation of the P1-P4 multi-helix junction is dependent on a cluster of metal ions and that this structure contributes to catalysis. ${ }^{109}$ Further corroboration for metal binding in $\mathrm{P} 4$ comes from NMR studies that demonstrate specific magnesium binding sites in a stem-loop that serves as a model for the P4 helix. ${ }^{103,110}$ Furthermore the $\mathrm{P}$ protein is proposed to stabilize the local $\mathrm{P}$ RNA structure near $\mathrm{P} 4 .^{23,58}$ These data, together with structural holoenzyme models placing the $\mathrm{P}$ protein near P RNA helix P4, suggest that the P protein could stabilize the P RNA structure to enhance the affinity of one or more metal ions bound to helix P4 and to facilitate catalysis. ${ }^{77}$

\section{CONCLUSIONS}

RNase P catalyzes the maturation of the $5^{\prime}$ end of pre-tRNAs in a metal dependent manner. The bacterial $\mathrm{P}$ protein sub- unit interacts with both the P RNA subunit and with the substrate, pre-tRNA. RNA-protein interactions play a variety of crucial roles in the essential ribonucleoprotein RNase P. The preponderance of evidence indicates that P RNA-protein interactions do not play a direct role in stabilizing the transition state of the reaction catalyzed by RNase P. However, protein-RNA interactions make several significant and essential contributions to catalysis by (a) stabilizing the structure of $\mathrm{P}$ RNA, (b) interacting with the pre-tRNA substrate to enhance affinity, and (c) reducing the dependence on magnesium ions. Despite the fact that RNase $\mathrm{P}$ has generally been regarded as noteworthy in the literature because it is large catalytic RNA, it is imperative to not underestimate the importance of the synergy between the RNA and protein components in this enzyme. Although several roles for the RNAprotein interactions have been clearly delineated, there are still more proposed functions that need further investigation.

The authors thank Drs. Katrin Karbstein, Marcy Hernick, Nathan Zahler, and Markos Koutmos for insightful discussion and comments.

\section{REFERENCES}

1. Noller, H. F. Science 2005, 309, 1508-1514

2. Wilson, K. S.; Noller, H. F. Cell 1998, 92, 337-349.

3. Patel, A. A.; Steitz, J. A. Nat Rev Mol Cell Biol 2003, 4, 960970.

4. Staley, J. P.; Guthrie, C. Cell 1998, 92, 315-326.

5. Autexier, C.; Lue, N. F. Annu Rev Biochem 2006, 75, 493-517.

6. Meier, U. T. Chromosoma 2005, 114, 1-14.

7. Torres-Larios, A.; Swinger, K. K.; Pan, T.; Mondragon, A. Curr Opin Struct Biol 2006, 16, 327-335.

8. Evans, D.; Marquez, S. M.; Pace, N. R. Trends Biochem Sci 2006, 31, 333-341.

9. Gopalan, V.; Vioque, A.; Altman, S. J Biol Chem 2002, 277, 6759-6762.

10. Li, Y.; Altman, S. Proc Natl Acad Sci USA 2003, 100, 1321313218.

11. Peck-Miller, K. A.; Altman, S. J Mol Biol 1991, 221, 1-5.

12. Komine, Y.; Kitabatake, M.; Yokogawa, T.; Nishikawa, K.; Inokuchi, H. Proc Natl Acad Sci USA 1994, 91, 9223-9227.

13. Haebel, P. W.; Gutmann, S.; Ban, N. Curr Opin Struct Biol 2004, 14, 58-65.

14. Altman, S.; Wesolowski, D.; Guerrier-Takada, C.; Li, Y. Proc Natl Acad Sci USA 2005, 102, 11284-11289.

15. Li, Y.; Cole, K.; Altman, S. RNA 2003, 9, 518-532.

16. Trang, P.; Kim, K.; Liu, F. Cell Microbiol 2004, 6, 499-508.

17. Willkomm, D. K.; Gruegelsiepe, H.; Goudinakis, O.; Kretschmer-Kazemi Far, R.; Bald, R.; Erdmann, V. A.; Hartmann, R. K. Chembiochem 2003, 4, 1041-1048.

18. Gossringer, M.; Kretschmer-Kazemi Far, R.; Hartmann, R. K. J Bacteriol 2006, 188, 6816-6823.

19. Kurz, J. C.; Niranjanakumari, S.; Fierke, C. A. Biochemistry $1998,37,2393-2400$ 
20. Sun, L.; Campbell, F. E.; Zahler, N. H.; Harris, M. E. Embo J 2006, 25, 3998-4007.

21. Kurz, J. C.; Fierke, C. A. Biochemistry 2002, 41, 9545-9558.

22. Buck, A. H.; Kazantsev, A. V.; Dalby, A. B.; Pace, N. R. Nat Struct Mol Biol 2005, 12, 958-964.

23. Buck, A. H.; Dalby, A. B.; Poole, A. W.; Kazantsev, A. V.; Pace, N. R. EMBO J 2005, 24, 3360-3368.

24. Guerrier-Takada, C.; Gardiner, K.; Marsh, T.; Pace, N.; Altman, S. Cell 1983, 35, 849-857.

25. Kikovska, E.; Svard, S. G.; Kirsebom, L. A. Proc Natl Acad Sci USA 2007, 104, 2062-2067.

26. Hall, T. A.; Brown, J. W. RNA 2002, 8, 296-306.

27. Niranjanakumari, S.; Kurz, J. C.; Fierke, C. A. Nucleic Acids Res 1998, 26, 3090-3096.

28. Beebe, J. A.; Fierke, C. A. Biochemistry 1994, 33, 10294-10304.

29. Beebe, J. A.; Kurz, J. C.; Fierke, C. A. Biochemistry 1996, 35, 10493-10505.

30. Doudna, J. A.; Cech, T. R. Nature 2002, 418, 222-228.

31. DeRose, V. J. Chem Biol 2002, 9, 961-969.

32. Hanna, R.; Doudna, J. A. Curr Opin Chem Biol 2000, 4, 166170.

33. Hsieh, J.; Andrews, A. J.; Fierke, C. A. Biopolymers 2004, 73, 79-89.

34. Harris, M. E.; Christian, E. L. Curr Opin Struct Biol 2003, 13, 325-333.

35. Terada, A.; Honda, T.; Fukuhara, H.; Hada, K.; Kimura, M. J Biochem (Tokyo) 2006, 140, 293-298.

36. Tsai, H. Y.; Pulukkunat, D. K.; Woznick, W. K.; Gopalan, V. Proc Natl Acad Sci USA 2006, 103, 16147-16152.

37. Chamberlain, J. R.; Lee, Y.; Lane, W. S.; Engelke, D. R. Genes Dev 1998, 12, 1678-1690.

38. Frank, D. N.; Adamidi, C.; Ehringer, M. A.; Pitulle, C.; Pace, N. R. RNA 2000, 6, 1895-1904.

39. Brown, J. W.; Haas, E. S.; James, B. D.; Hunt, D. A.; Liu, J. S.; Pace, N. R. J Bacteriol 1991, 173, 3855-3863.

40. Day-Storms, J. J.; Niranjanakumari, S.; Fierke, C. A. RNA 2004, 10, 1595-1608.

41. Wegscheid, B.; Condon, C.; Hartmann, R. K. EMBO Rep 2006, 7, 411-417.

42. Pannucci, J. A.; Haas, E. S.; Hall, T. A.; Harris, J. K.; Brown, J. W. Proc Natl Acad Sci USA 1999, 96, 7803-7808.

43. Brown, J. W.; Pace, N. R. Biochimie 1991, 73, 689-697.

44. Loria, A.; Pan, T. RNA 1996, 2, 551-563.

45. Pan, T.; Loria, A.; Zhong, K. Proc Natl Acad Sci USA 1995, 92, 12510-12514.

46. Loria, A.; Pan, T. Nucleic Acids Res 2001, 29, 1892-1897.

47. Westhof, E.; Altman, S. Proc Natl Acad Sci USA 1994, 91, 5133-5137.

48. Harris, M. E.; Nolan, J. M.; Malhotra, A.; Brown, J. W.; Harvey, S. C.; Pace, N. R. EMBO J 1994, 13, 3953-3963.

49. Krasilnikov, A. S.; Yang, X.; Pan, T.; Mondragon, A. Nature 2003, 421, 760-764.

50. Krasilnikov, A. S.; Xiao, Y.; Pan, T.; Mondragon, A. Science 2004, 306, 104-107.

51. Kazantsev, A. V.; Krivenko, A. A.; Harrington, D. J.; Holbrook, S. R.; Adams, P. D.; Pace, N. R. Proc Natl Acad Sci USA 2005, 102, 13392-13397.

52. Torres-Larios, A.; Swinger, K. K.; Krasilnikov, A. S.; Pan, T.; Mondragon, A. Nature 2005, 437, 584-587.
53. Pomeranz Krummel, D. A.; Altman, S. RNA 1999, 5, 10211033.

54. Walker, S. C.; Engelke, D. R. Crit Rev Biochem Mol Biol 2006, 41, 77-102.

55. Jovanovic, M.; Sanchez, R.; Altman, S.; Gopalan, V. Nucleic Acids Res 2002, 30, 5065-5073.

56. Zahler, N. H.; Sun, L.; Christian, E. L.; Harris, M. E. J Mol Biol 2005, 345, 969-985.

57. Loria, A.; Pan, T. Biochemistry 1998, 37, 10126-10133.

58. Niranjanakumari, S.; Day-Storms, J. J.; Ahmed, M.; Hsieh, J.; Zahler, N. H.; Venters, R. A.; Fierke, C. A. RNA 2007, 13, 512-535.

59. Tsai, H. Y.; Masquida, B.; Biswas, R.; Westhof, E.; Gopalan, V. J Mol Biol 2003, 325, 661-675.

60. Rox, C.; Feltens, R.; Pfeiffer, T.; Hartmann, R. K. J Mol Biol 2002, 315, 551-560.

61. Kole, R.; Baer, M. F.; Stark, B. C.; Altman, S. Cell 1980, 19, 881-887.

62. Sun, L.; Harris, M. E. RNA 2007, 13, 1505-1515.

63. Talbot, S. J.; Altman, S. Biochemistry 1994, 33, 1406-1411.

64. Tallsjo, A.; Kirsebom, L. A. Nucleic Acids Res 1993, 21, 51-57.

65. Loria, A.; Niranjanakumari, S.; Fierke, C. A.; Pan, T. Biochemistry 1998, 37, 15466-15473.

66. Westhof, E.; Wesolowski, D.; Altman, S. J Mol Biol 1996, 258, 600-613.

67. Crary, S. M.; Niranjanakumari, S.; Fierke, C. A. Biochemistry 1998, 37, 9409-9416.

68. Niranjanakumari, S.; Stams, T.; Crary, S. M.; Christianson, D. W.; Fierke, C. A. Proc Natl Acad Sci USA 1998, 95, 1521215217.

69. Rueda, D.; Hsieh, J.; Day-Storms, J. J.; Fierke, C. A.; Walter, N. G. Biochemistry 2005, 44, 16130-16139.

70. Stams, T.; Niranjanakumari, S.; Fierke, C. A.; Christianson, D. W. Science 1998, 280, 752-755.

71. Gopalan, V.; Golbik, R.; Schreiber, G.; Fersht, A. R.; Altman, S. J Mol Biol 1997, 267, 765-769.

72. Spitzfaden, C.; Nicholson, N.; Jones, J. J.; Guth, S.; Lehr, R.; Prescott, C. D.; Hegg, L. A.; Eggleston, D. S. J Mol Biol 2000, 295, 105-115.

73. Kazantsev, A. V.; Krivenko, A. A.; Harrington, D. J.; Carter, R. J.; Holbrook, S. R.; Adams, P. D.; Pace, N. R. Proc Natl Acad Sci USA 2003, 100, 7497-7502.

74. Wilson, R. C.; Bohlen, C. J.; Foster, M. P.; Bell, C. E. Proc Natl Acad Sci USA 2006, 103, 873-878.

75. Massire, C.; Jaeger, L.; Westhof, E. J Mol Biol 1998, 279, 773793.

76. Frank, D. N.; Pace, N. R. Annu Rev Biochem 1998, 67, 153180.

77. Crary, S. M.; Kurz, J. C.; Fierke, C. A. RNA 2002, 8, 933-947.

78. Christian, E. L.; Zahler, N. H.; Kaye, N. M.; Harris, M. E. Methods 2002, 28, 307-322.

79. Christian, E. L.; Kaye, N. M.; Harris, M. E. RNA 2000, 6, 511519.

80. Guo, X.; Campbell, F. E.; Sun, L.; Christian, E. L.; Anderson, V. E.; Harris, M. E. J Mol Biol 2006, 360, 190-203.

81. Oh, B. K.; Frank, D. N.; Pace, N. R. Biochemistry 1998, 37, 7277-7283.

82. Henkels, C. H.; Kurz, J. C.; Fierke, C. A.; Oas, T. G. Biochemistry 2001, 40, 2777-2789. 
83. Fang, X. W.; Yang, X. J.; Littrell, K.; Niranjanakumari, S.; Thiyagarajan, P.; Fierke, C. A.; Sosnick, T. R.; Pan, T. RNA 2001, 7, 233-241.

84. Barrera, A.; Fang, X.; Jacob, J.; Casey, E.; Thiyagarajan, P.; Pan, T. Biochemistry 2002, 41, 12986-12994.

85. Hartmann, R. K.; Heinrich, J.; Schlegl, J.; Schuster, H. Proc Natl Acad Sci USA 1995, 92, 5822-5826.

86. Hardt, W. D.; Schlegl, J.; Erdmann, V. A.; Hartmann, R. K. Biochemistry 1993, 32, 13046-13053.

87. Zahler, N. H.; Christian, E. L.; Harris, M. E. RNA 2003, 9 , 734-745.

88. Oh, B. K.; Pace, N. R. Nucleic Acids Res 1994, 22, 4087-4094.

89. Hardt, W. D.; Schlegl, J.; Erdmann, V. A.; Hartmann, R. K. J Mol Biol 1995, 247, 161-172.

90. Brannvall, M.; Pettersson, B. M.; Kirsebom, L. A. J Mol Biol 2003, 325, 697-709.

91. Kirsebom, L. A.; Svard, S. G. EMBO J 1994, 13, 4870-4876.

92. Brannvall, M.; Fredrik Pettersson, B. M.; Kirsebom, L. A. Biochimie 2002, 84, 693-703.

93. Busch, S.; Kirsebom, L. A.; Notbohm, H.; Hartmann, R. K. J Mol Biol 2000, 299, 941-951.

94. Loria, A.; Pan, T. Biochemistry 1997, 36, 6317-6325.

95. Loria, A.; Pan, T. Biochemistry 1999, 38, 8612-8620.

96. Fahlman, R. P.; Dale, T.; Uhlenbeck, O. C. Mol Cell 2004, 16, 799-805.

97. LaRiviere, F. J.; Wolfson, A. D.; Uhlenbeck, O. C. Science 2001, 294, 165-168.
98. Lott, W. B.; Pontius, B. W.; von Hippel, P. H. Proc Natl Acad Sci USA 1998, 95, 542-547.

99. Gondert, M. E.; Tinsley, R. A.; Rueda, D.; Walter, N. G. Biochemistry 2006, 45, 7563-7573.

100. Smith, D.; Pace, N. R. Biochemistry 1993, 32, 5273-5281.

101. Pan, T. Biochemistry 1995, 34, 902-909.

102. Christian, E. L.; Smith, K. M.; Perera, N.; Harris, M. E. RNA 2006, 12, 1463-1467.

103. Getz, M. M.; Andrews, A. J.; Fierke, C. A.; Al-Hashimi, H. M. RNA 2007, 13, 251-266.

104. Gardiner, K. J.; Marsh, T. L.; Pace, N. R. J Biol Chem 1985, 260, 5415-5419.

105. Reich, C.; Olsen, G. J.; Pace, B.; Pace, N. R. Science 1988, 239, 178-181.

106. Record, M. T., Jr.; Anderson, C. F.; Lohman, T. M. Q Rev Biophys 1978, 11, 103-178.

107. Gluick, T. C.; Gerstner, R. B.; Draper, D. E. J Mol Biol 1997, 270, 451-463.

108. Waugh, D. S.; Pace, N. R. Faseb J 1993, 7, 188-195.

109. Kaye, N. M.; Christian, E. L.; Harris, M. E. Biochemistry 2002, $41,4533-4545$.

110. Schmitz, M.; Tinoco, I., Jr. RNA 2000, 6, 1212-1225.

Reviewing Editor: Katrin Karbstein 